\title{
Correlation among Snpb11 markers, root growth, and physiological characters of upland rice under aluminum stress
}

\author{
MIFTAHUL HUDA FENDIYANTO ${ }^{1}$, RIZKY DWI SATRIO ${ }^{1}$, SUHARSONO $^{2,3}$, ARIS TJAHJOLEKSONO ${ }^{2}$, \\ MIFTAHUDIN ${ }^{2, \vee v}$ \\ ${ }^{1}$ Plant Biology Graduate Program, Department of Biology, Faculty of Mathematics and Natural Sciences, Institut Pertanian Bogor. Jl. Raya Dramaga, \\ Kampus IPB Darmaga, Bogor 16680, West Java, Indonesia \\ ${ }^{2}$ Department of Biology, Faculty of Mathematics and Natural Sciences, Institut Pertanian Bogor. Jl. Raya Dramaga, Kampus IPB Darmaga, Bogor 16680, \\ West Java, Indonesia. Tel./fax.: +62-251-8622833, ״v email: miftahudinm@gmail.com. \\ ${ }^{3}$ Research Center for Bioresources and Biotechnology, Institut Pertanian Bogor. Jl. Raya Dramaga, Kampus IPB Darmaga, Bogor 16680, West Java, \\ Indonesia
}

Manuscript received: 8 April. Revision accepted: 18 April 2019.

\begin{abstract}
Fendiyanto MH, Satrio RD, Suharsono, Tjahjoleksono A, Miftahudin. 2019. Correlation among Snpb11 markers, root growth, and physiological characters of upland rice under aluminum stress. Biodiversitas 20: 1243-1254. The cultivation of upland rice in acid soils faces aluminum (Al) toxicity. Development of Al-tolerant rice could be one of the solutions to overcome the problem. Markerassisted breeding to develop Al-tolerant rice requires at least a molecular marker for foreground selection. Snpb11 is a molecular marker developed from the nucleotide differences in a specific allele between Al-tolerant and sensitive rice. Snpb11 has never been used as a molecular marker in rice. Therefore this study aimed to examine the correlation among Snpb11 marker, root growth, and physiological characters under $\mathrm{Al}$ stress in upland rice. We used physiological characters and the Snpb11 marker to justify the Al tolerance level in several upland rice varieties. We found that physiological characters, i.e.: primary root length, total root length, chlorophyll, and carotenoid content showed positive correlation to Snpb11. Conversely, root malondialdehyde content, which represents the level of lipid peroxidation showed a negative correlation to Snpb11. There is evidence that the Snpb11 highly correlated with primary and total root length characters, which are the Al tolerance parameters used in rice. Therefore, Snpbll markers can be used to distinguish the Al tolerance level in upland rice.
\end{abstract}

Keywords: Aluminum, Inpago, malondialdehyde, rice, SNP

\section{INTRODUCTION}

Food demand in Indonesia, especially rice, increases from year to year, but the area of rice cultivation continues to decrease due to the conversion of rice fields into settlements and industries. One effort that can be done to increase rice production is to extend rice cultivation area to marginal land such as red-yellow podzolic acid soils that dominate outside Java Island (Karama and Abdurrachman 1993; Lynch and Saint-Clair 2004). Unfortunately, crop cultivation in acid soils, including rice, will face a problem with high aluminum (Al) solubility (Kochian 1995). There are several solutions to overcome the $\mathrm{Al}$ toxicity problem in acid soils, which one of them is using $\mathrm{Al}$ tolerant rice varieties. Rice genetic improvement to develop Al-tolerant rice varieties could be done using conventional breeding, marker-assisted breeding, or/and genetic engineering approaches. To perform marker-assisted breeding or genetic engineering, searching for molecular markers is a compulsory preliminary step before identification, isolation, and cloning a gene (Kochian et al. 2004; Sasaki et al. 2004)

Aluminum tolerance in rice is controlled by many genes (Nguyen et al. 2001; Nguyen et al. 2003; Tsutsui et al. 2011; Yamaji et al. 2009). Determination of Al tolerance level in plants is generally carried out in complex and comprehensive ways using several physiological characters
(Awasthi et al. 2017; Panda et al. 2009). There are various physiological characters that can be used to determine $\mathrm{Al}$ tolerance level including root growth characters (Kochian et al. 2015; Ma et al. 2014), accumulation of $\mathrm{Al}$ in the root tip (Awasthi et al. 2017), the level of lipid peroxidation in the root (Siska et al. 2017; Jumiati 2016), and chlorophyll content in the leaves (Sen et al. 2014). The character of root length is a major character determining $\mathrm{Al}$ tolerance level because the root organ is an organ that is directly exposed to $\mathrm{Al}$ in the rhizosphere (Roy and Bhadra 2014; Kochian et al. 2015, Ma et al. 2014). Some examples of the root length characters that determine $\mathrm{Al}$ tolerance level are root re-growth (RRG) (Roslim 2011; Jumiati 2016; Umaiyah 2016), root growth inhibition (RGI) (Siska et al. 2017), primary relative root length (RRL) (Wijayanto 2013), primary root length (PRL), total root length (TRL), lateral root length (LRL), and lateral root count (LRC) (Siska et al. 2017). However, there are some problems in using the root length character as a determinant character of the $\mathrm{Al}$ tolerance level in the plant. The use of RRG and RGI characters could not clearly distinguish Al tolerance levels among several rice genotypes (Siska et al. 2017; Wijayanto 2013). QTL detection of Al tolerance in rice has been difficult due to relatively low LOD value when using the RRL character as an $\mathrm{Al}$ tolerance parameter (Wijayanto 2013). The use of many characters of root length in certain plants has not been able to conclude the tolerance level of 
the plants. Al tolerance level may not depend merely on root length character due to the differences in root systems architecture (RSA) in various types of rice genotypes (Jung and McCouch 2013). Therefore, the determination of the $\mathrm{Al}$ tolerance level in rice requires a comprehensive physiological approach.

The use of physiological characters based on the $\mathrm{Al}$ accumulation in the root tip and the level of lipid peroxidation have been carried out to determine the tolerance level in rice (Awasthi et al. 2017; Siska et al. 2017; Jumiati 2016). Transgenic rice cV. IR64 overexpressed $\mathrm{Al}$ tolerance gene candidate shows an increase in $\mathrm{Al}$ tolerance compared to its wild type based on $\mathrm{Al}$ accumulation in the root tip and the level of lipid peroxidation (Siska et al. 2017). Other research shows that Al treatment to plants affects the function of photosynthetic devices and reduce chlorophyll content (Ohki 1986; Sen et al. 2014; Mihailovic et al. 2008) although there is a hypothesis states that the chlorophyll content of the leaves has no effect on Al tolerance level because it is a secondary symptom (Akaya and Takenaka 2001). Therefore, it is important to determine whether chlorophyll content correlates with the $\mathrm{Al}$ tolerance level in rice.

The role of molecular markers in plant genetics and improvement has been widely recognized and the most recent molecular markers that are widely used are single nucleotide polymorphism (SNP) marker. Snpb11 is an SNP marker developed from B11CAPS, a cleaved amplified polymorphism sequence (CAPS) marker developed from the DNA sequence of B11 alleles of Al-tolerant and sensitive rice. The B11CAPS marker has been proved as a marker that is able to distinguish between Al-tolerant and sensitive rice plants in an F2 population derived from a cross between rice cv IR64 and Hawara Bunar (Roslim 2011). Snpb11 has never been used as a molecular marker in rice and need to be validated. Based on the preliminary test using root length characters, Inpago is improved upland rice that is sensitive to $\mathrm{Al}$ in hydroponically nutrient culture. In addition, Inpago rice has not been tested for its tolerance level to $\mathrm{Al}$ in the vegetative phase, especially in the rice seedling stage. Therefore, this study aimed to evaluate the correlation between the Snpbl1 marker and the $\mathrm{Al}$-tolerance parameter in upland rice under $\mathrm{Al}$ stress.

\section{MATERIALS AND METHODS}

\section{Materials}

Materials used in this research are seeds and DNA from rice cv. Hawara Bunar, Hawara Bunar mutant, B11silenced Hawara Bunar, IR64, Inpago 4, Inpago 5, Inpago 6, Inpago 7, Inpago 8, Inpago 9, Inpago 10, Inpago 11, Limboto, Batutugi, Jatiluhur, Situ Patenggang, and Situ Bagendit. The seeds of Hawara Bunar and IR64 were obtained from the collection of Laboratory of Plant Physiology and Molecular Biology, Department of Biology, IPB, Bogor, Indonesia, while other rice cultivars were obtained from Rice Field Laboratory Muara Ciapus, Rice Research Agency, Center for Agriculture Research and Development, Department of Agriculture.

\section{Minimum nutrient culture and Al treatment}

Rice seeds are sterilized using $0.5 \%(\mathrm{v} / \mathrm{v}) \mathrm{NaOCl}$ for 15 minutes. After that, the seed was rinsed with distilled water 3 times and was then soaked in distilled water for 48 hours at $27^{\circ} \mathrm{C}$. Rice seeds were germinated for 24 hours in a dark room at room temperature. The rice seedlings with a $0.5-1$ $\mathrm{cm}$ root length were then grown on plastic net floating on aerated minimum nutrient culture media (Miftahudin et al. 2002; Miftahudin et al. 2008) without $\mathrm{Al}$ at $\mathrm{pH} 4.0$ for 24 hours. After that, the seedlings were treated with $15 \mathrm{ppm}$ Al for 72 hours. For root length difference (RLD) and root length effect (RLE) observation, several seedlings were then grown on nutrient media without $\mathrm{Al}$ for 48 hours to recover the root growth. Nutrient culture treatments were carried out in a controlled growth chamber with a temperature of $29-31^{\circ} \mathrm{C}, 80 \%$ relative humidity with 12 hours of light and 12 hours of dark. The nutrient solution is replaced daily to maintain a $\mathrm{pH}$ of 4.0. The experiment was replicated three times.

\section{Root growth analysis}

Following the Al treatment, root seedlings were scanned using Epson Perfection V370 Photo Scanner to produce black and white images, and then the root images were measured for primary root length (PRL), total root length (TRL), primary root growth inhibition (RGI), relative primary root length (RRL), RLD, and RLE using Image J (Piere et al. 2013) and RootReader2D (Clark et al. 2013) software. PRL is the average of primary root length, while TRL is the average of total root length in all replications ( $n=30$, respectively) in each genotype at 15 ppm Al stress 72 hours. Moreover, RGI, RRL, RLD, and RLE were calculated using the following formulas adopted from Roslim (2011), Siska et al. (2017), and Nguyen et al. (2003):

$$
\begin{aligned}
& \text { RGI }=\frac{\Delta \text { control }-\Delta \text { treatment }}{\Delta \text { control }} \times 100 \\
& \text { RRL }=\frac{\Delta \text { treatment }}{\Delta \text { control }} \\
& \text { RLD }=\Delta \text { (recovery }- \text { stress }) \\
& \text { RLE }=\Delta \text { control }^{\prime}-\Delta \text { treatment }^{\prime}
\end{aligned}
$$

\section{Where:}

$\Delta$ control : the differences of main root length between stress period and adaptation period without $\mathrm{Al}$ stress. $\Delta$ treatment : the differences of main root length between stress period and adaptation period with $15 \mathrm{ppm} \mathrm{Al}$.

$\Delta$ control' : the differences of main root length between stress period and recovery period without $\mathrm{Al}$ stress.

$\Delta$ treatment' : the differences of main root length between stress period and recovery period with $15 \mathrm{ppm} \mathrm{Al}$.

recovery : the root length in the recovery period without Al stress.

stress : the root length in the stress period with 15 ppm Al. 


\section{Chlorophyll and carotenoid content analysis}

Leaf chlorophyll and carotenoid content were determined following the procedure of Dere et al. (1998) with slightly modified by $\mathrm{Hu}$ et al. (2013). An amount of $0.1 \mathrm{~g}$ of rice leaves was ground using the mortar and homogenized by adding $10 \mathrm{ml}$ of $100 \%$ acetone. The mixture was then centrifuged at $1000 \mathrm{rpm}$ for one minute. The supernatant was removed and then re-centrifuged at $2500 \mathrm{rpm}$ for ten minutes. The absorbance of the supernatant was measured using a spectrophotometer at wavelengths 470, 646 and $662 \mathrm{~nm}$. The experiment was conducted with three biological replications and three technical replications. Calculation of total chlorophyll content including chlorophyll a, chlorophyll b, and carotenoid was carried out following the formula of Dere et al. (1998).

\section{Histochemical analysis of aluminum accumulation in the rice roots}

Histochemical analysis of aluminum accumulation in the root was performed using Ehrlich's Aluminum hematoxylin method. This followed Siska et al. (2017) method. The root of rice seedlings was rinsed using distilled water after $\mathrm{Al}$ treatment for 2 minutes, then immersed in $0.6 \%(\mathrm{w} / \mathrm{v})$ hematoxylin solution for 2 minutes and rinsed with distilled water. Al accumulation was shown with the presence of purple color on the root tip (Miftahudin et al. 2007). Al accumulation was observed using an Olympus SZ51 stereomicroscope (Olympus, Japan) equipped with an Optilab camera (Miconos, Indonesia).

\section{Quantitative analysis of lipid peroxidation}

Quantitative analysis of lipid peroxidation was carried out based on the malondialdehyde (MDA) concentration in the sample. This followed the method of Siska et al. (2017). An amount of $0.3 \mathrm{~g} 1.5 \mathrm{~cm}$ root tips were ground with a mortar, added $5 \mathrm{ml} 0.1 \%$ (w/v) Trichloroacetic acid (TCA), and, then centrifuged at $10.000 \mathrm{~g}$ for 5 minutes. After centrifugation, $1 \mathrm{ml}$ of supernatant was moved to a new tube, added by $4 \mathrm{ml}$ of $0.1 \%$ (w/v) Thiobarbituric acid (TBA) in $20 \%(\mathrm{w} / \mathrm{v})$ TCA. The solution was then incubated at $80^{\circ} \mathrm{C}$ in a water bath for 30 minutes and then cooled to room temperature. The absorbance of the TBA-MDA complex was measured using a spectrophotometer at a wavelength $(\lambda) 532 \mathrm{~nm}$, whereas non-specific absorbance measured at a wavelength $(\lambda) 600 \mathrm{~nm}$ (Meriga et al. 2010). Plant roots without Al treatment were used as a control. The MDA content was determined based on the following Heath and Packer (1968) formula:

$$
[\mathrm{MDA}]=\frac{\left(\frac{A 532-A 600}{\varepsilon}\right) \times 10^{6}}{\text { Fresh weight }(\mathrm{g})}
$$

[MDA] : MDA concentration (nmol/g)

$\varepsilon \quad$ : MDA extension coefficient value $\left(155 \mathrm{mM}^{-1} \mathrm{~cm}^{-1}\right)$

\section{Identification of Snpb11 markers}

Snpbl1 markers were identified based on the sequence of B11CAPS marker developed from B11 gene that is isolated from Al-tolerant rice cv. Hawara Bunar and Alsensitive rice cv. IR64 (Roslim 2011). B11CAPS was PCR amplified. The undigested $500 \mathrm{bp}$ B11CAPS marker was sequenced using the ABI PRISM 310 Genetic Analyzer machine with BigDye Terminator v3.1 cycle sequencing kit (Applied Biosystems) to check SNP among rice genotypes. The B11CAPS sequences were multi-aligned among rice sequences using Clustal $\mathrm{W}$ with the default settings in the U-Gene program (Okonechnikov et al. 2012).

\section{Correlation analysis of Snpb11 marker and physiological characters}

The SNPs, root growth, and physiological characters were standardized and correlated using Pearson correlation on the $\mathrm{R}$ program with the library packages ggplot and corrplot. We used the intercorrelation method to visualize the relationship among the SNPs, root growth, physiological characters using the number and round symbol graph.

\section{Data analysis}

Data were analyzed with analysis of variance (ANOVA), and if there were significant differences among the data, a further test was carried out with the Tukey Test at a significance level of $\alpha=0.05$ using $\mathrm{R}$ program. Principal Component Analysis (PCA) was used to group rice genotypes using PAST 3.06 program. A dendrogram and heatmap Pearson correlations were made using the $\mathrm{R}$ version 3.5.1 program (https: //cran.r-project.org/, Lander 2014).

\section{RESULTS AND DISCUSSION}

\section{Root growth}

The responses of root growth to $\mathrm{Al}$ stress were qualitative and quantitatively observed after the rice seedlings being treated with $15 \mathrm{ppm} \mathrm{Al}$ in a nutrient solution. A qualitative data was the interpretation of root length and growth based on the images of rice root architecture produced from the scanned roots after 72 hours period of Al treatment. There was the variation on root architecture including root branch and length among rice cultivars (Figure 1). Rice cv. Hawara Bunar had the longest roots, whereas Situbagendit and Inpago 9 had relatively shortest roots. In general, Inpago rice has a shorter root length than that of Hawara Bunar under $\mathrm{Al}$ treatment.

Quantitative data was produced by measuring the primary root length (PRL) components, which includes primary root growth inhibition (RGI), and relative primary root length (RRL), root length difference (RLD), and root length effect (RLE) characters. Based on the RGI characters, rice cultivars Hawara Bunar, Limboto, Inpago 7 , and Batutugi were less inhibited by $\mathrm{Al}$ than that of cultivars Jatiluhur, Inpago 10, and Inpago 6 that showed high RGI value (Figure 2). Conversely, Rice cultivars Hawara Bunar, Limboto, Inpago 7, and Batutugi showed 
higher RRL values than that of cultivars Jatiluhur, Inpago 10, and Inpago 6 (Figure 2). The highest values of RLD character was found in rice cv Hawara Bunar, whereas the RLD of other cultivars were relatively low. RLE character indicates the differences between Al-stressed and nonstressed root length. Rice cv. Hawara Bunar has similar RLE value in both Al-treated and nontreated condition (Figure 2). Based on the quantitative measurement of primary root length characters, which is a parameter of the root ability to grow under Al stress, showed that rice cv. Hawara Bunar has longer primary root length than that of Inpago rice and other cultivars.

\section{Leaf chlorophyll and carotenoid content}

Leaf chlorophyll content varied among genotypes. A similar variation pattern was observed between chlorophyll-a and chlorophyll-b content among genotypes (Figure 3). The highest chlorophyll content was found in rice $\mathrm{cv}$. Hawara Bunar, Jatiluhur, Inpago 8, and Inpago 9 and the lowest chlorophyll content were found in var.
Limboto. Carotenoid content in rice leaves showed a similar pattern with that of leaf chlorophyll content. The highest carotenoid content found in rice cv. Hawara Bunar, Jatiluhur, Inpago 8, and Inpago 9 at $1900 \mathrm{mg} / \mathrm{g}^{-1} \mathrm{FW}$, whereas the lowest carotenoid content found in rice cv. Limboto, Batutugi, and Inpago 10 at 756, 978, and 1117 $\mathrm{mg} / \mathrm{g}^{-1} \mathrm{FW}$, respectively.

\section{Aluminum accumulation in the root tips}

Qualitative analysis of $\mathrm{Al}$ accumulation in the roots was performed using hematoxylin staining of the root tips after being treated with $15 \mathrm{ppm} \mathrm{Al}$. The $\mathrm{Al}$ accumulation was detected when the root color changed to purple and the level of accumulation was correlated with the intensity of root color. The result showed that rice root cv Hawara Bunar has less intense purple color than that of the other rice cultivars (Figure 4) indicated that cv. Hawara Bunar and Jatiluhur roots accumulated lower $\mathrm{Al}$ than that other rice cultivar, including rice cv IR64, which is sensitive to Al.

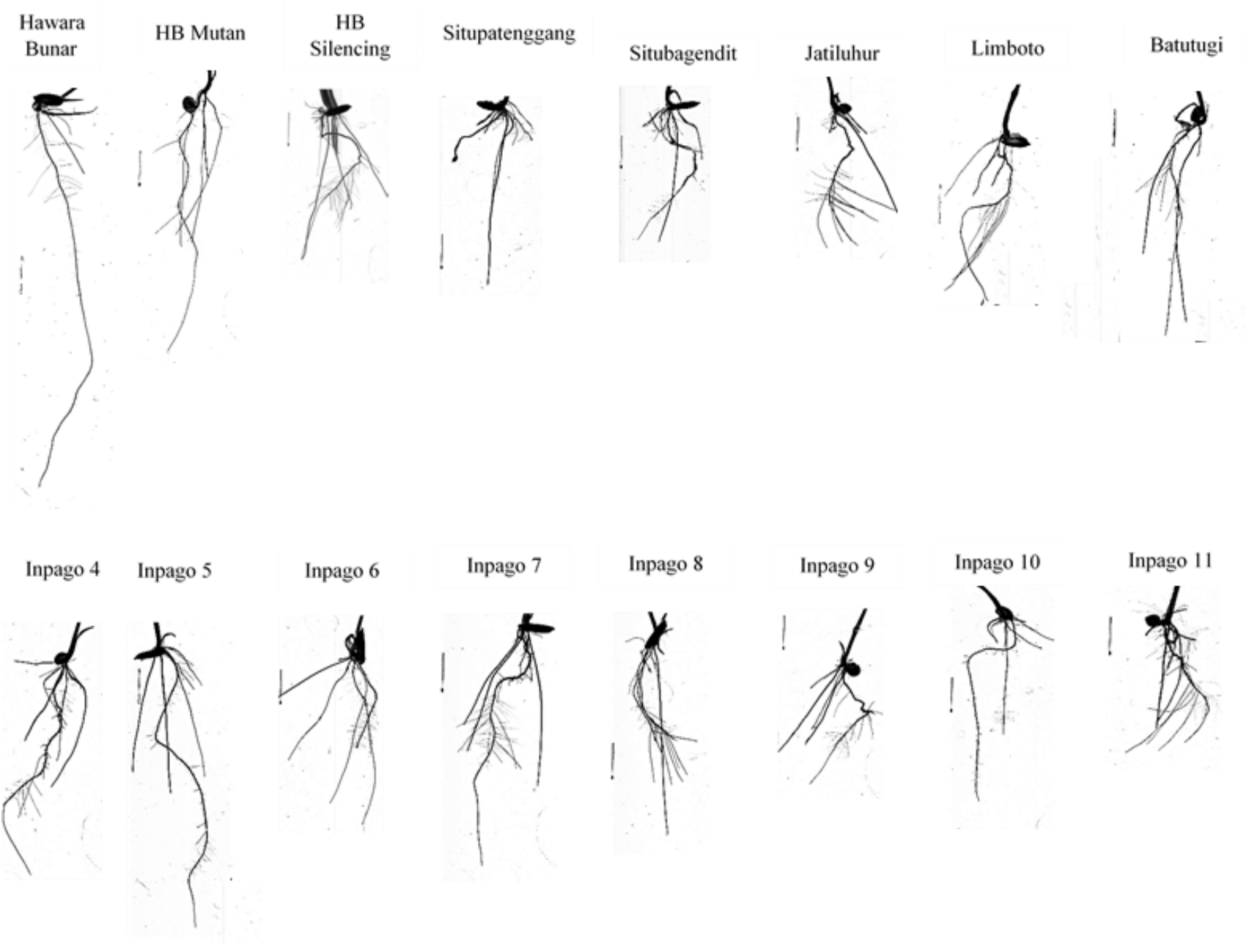

Figure 1 Root architecture profile of Inpago and other rice cultivars after Al-treatment for 72 hours at $\mathrm{pH} 4.0$. Bar=1 cm 

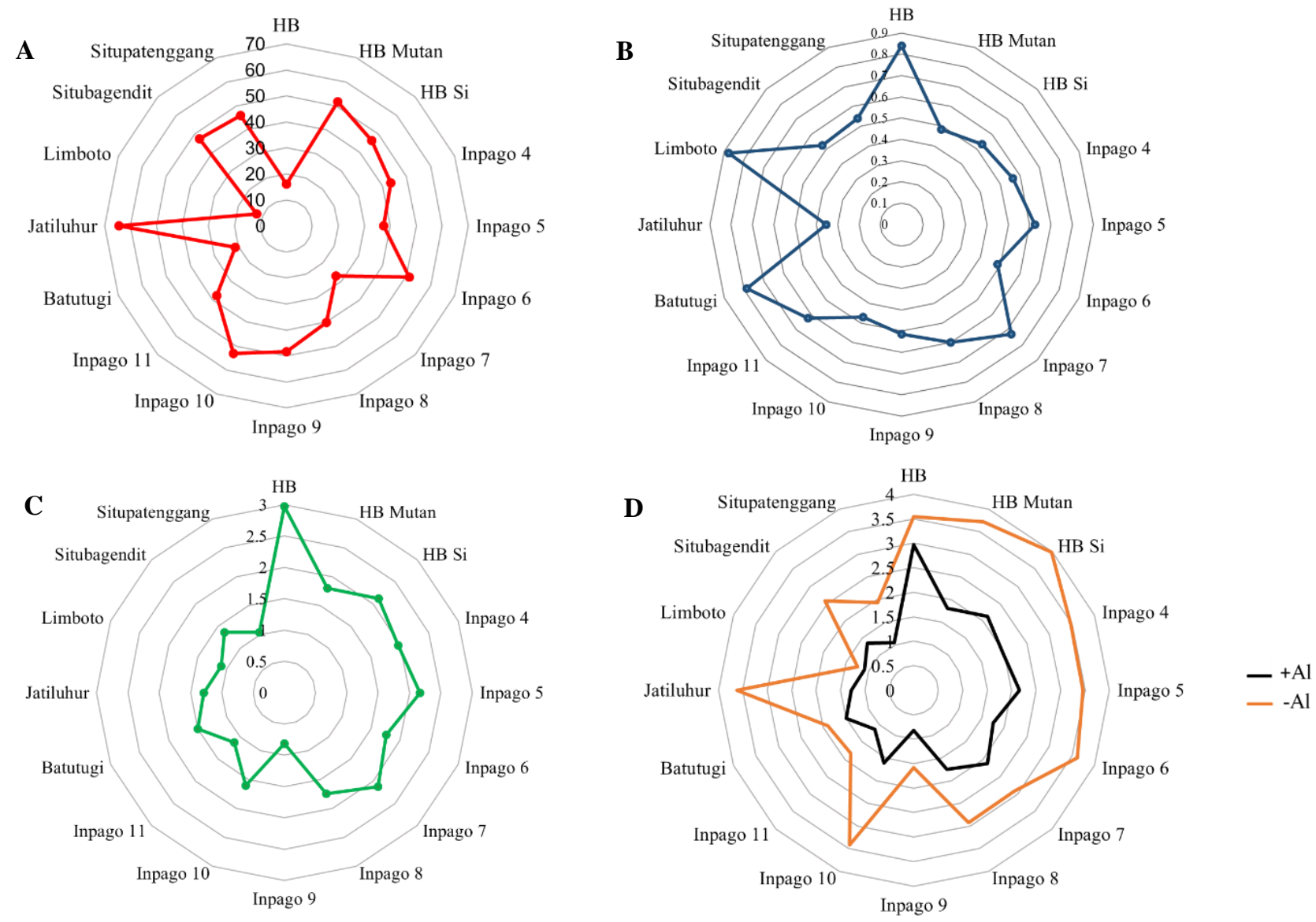

Figure 2 The comparison of primary root length in several Inpago rice genotypes treated by Al. Characters which are observed were (A) primary root growth inhibition (RGI), (B) relative primary root length (RRL), (C) root length difference (RLD), and (D) root length effect (RLE). Rice is adapted for 24 hours at a minimum nutrient culture $\mathrm{pH} 4.0$, then continue to treat with aluminum $15 \mathrm{ppm}$ for 72 hours pH 4.0 (Jumiati 2016). Each genotype is measured using three biological repeated and 12 technical repeated.

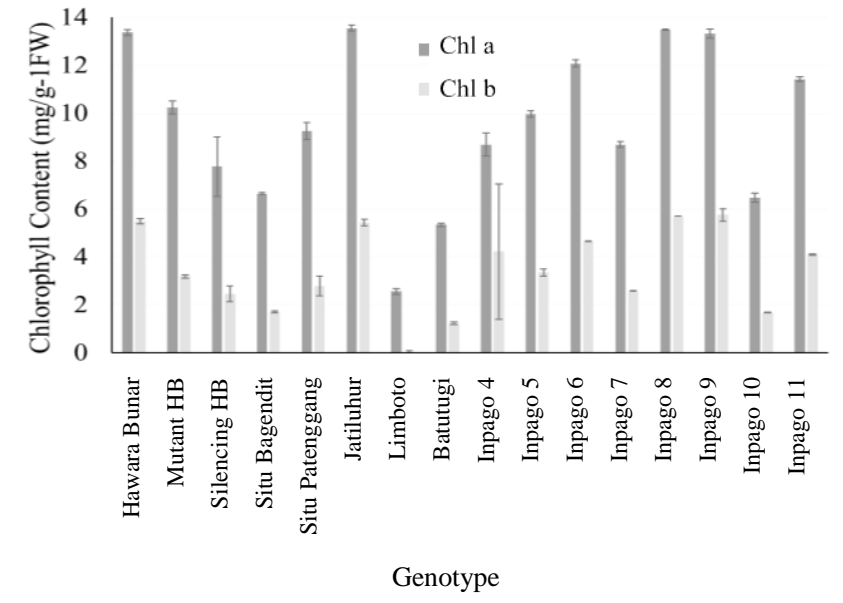

A

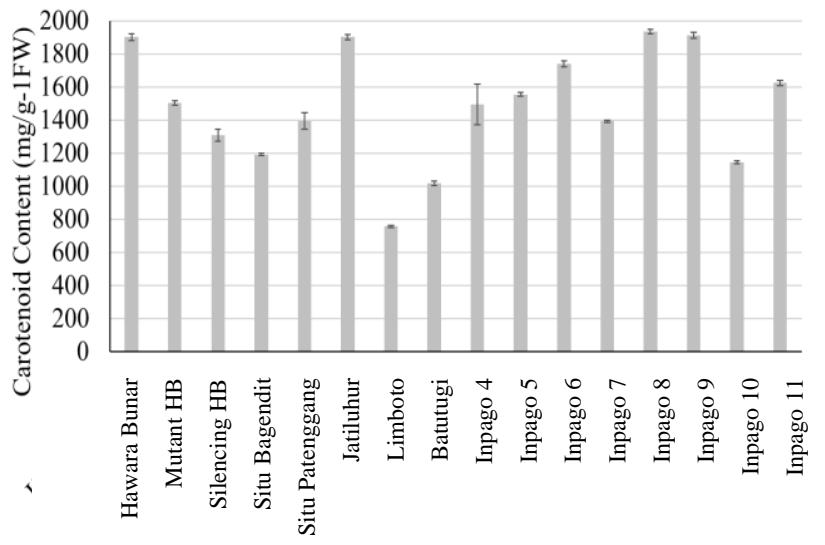

Genotype

B

Figure 3. The leaf chlorophyll-a ( $\mathrm{Chl}$ a), chlorophyll-b (Chl b) (A), and carotenoid content (B) of several rice genotypes under $\mathrm{Al}$ treatment. Hawara Bunar is a positive control genotype (Al-tolerant), while Mutant HB is a negative control (Al-sensitive). Rice seedlings were treated with $15 \mathrm{ppm} \mathrm{Al}$ for 72 hours at $\mathrm{pH} 4$. 


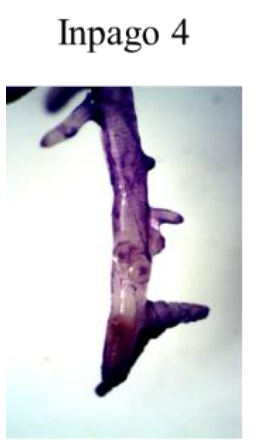

Inpago 9

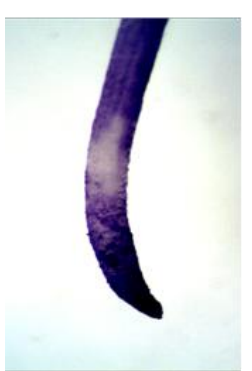

Inpago 5

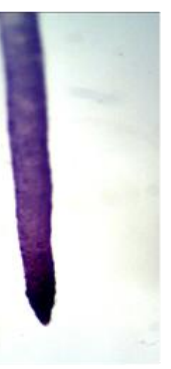

Inpago 10

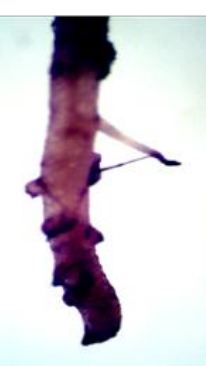

Inpago 6

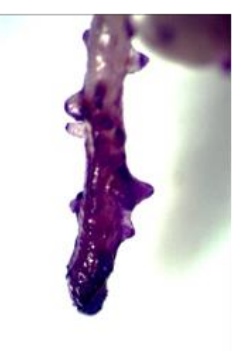

Inpago 11

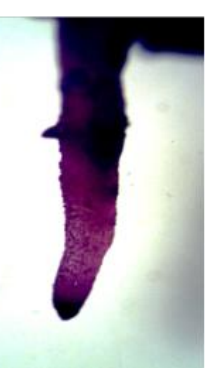

Inpago 7

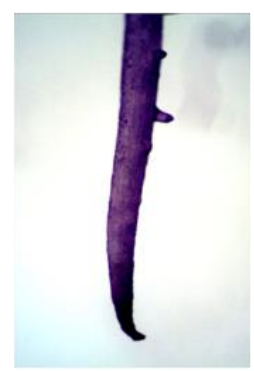

Situbagendit

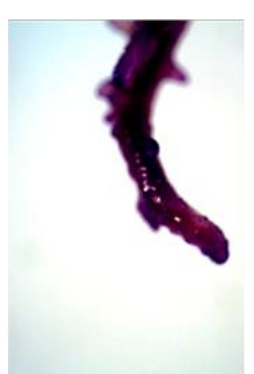

Inpago 8

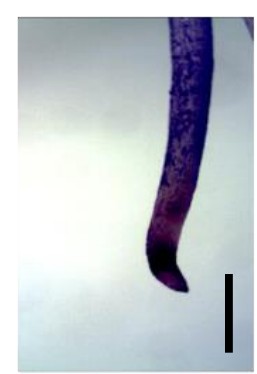

Hawarabunar

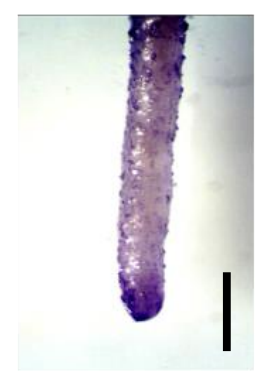

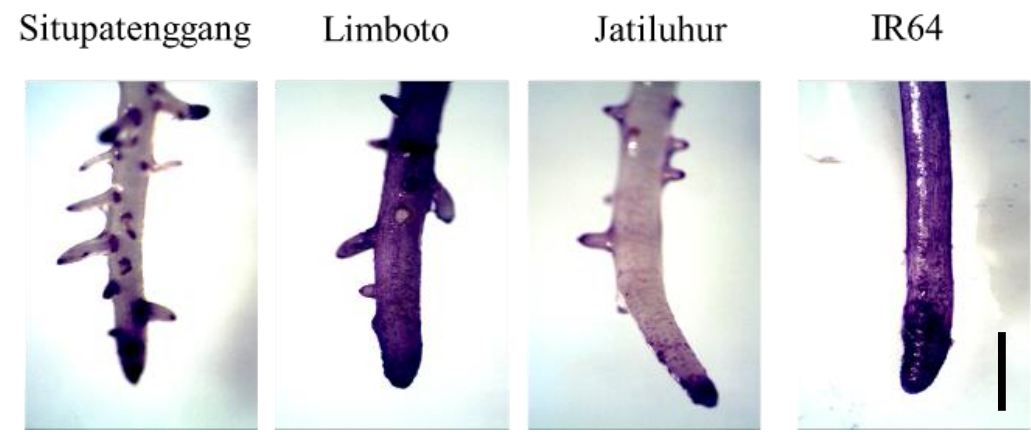

Figure 4. Histochemical analysis of $\mathrm{Al}$ accumulation on root tip of several rice genotypes after being stressed with $15 \mathrm{ppm}$ of $\mathrm{Al}$ for 72 hours. Rice cv. IR64, which is sensitive to Al stress was used as a negative control. Bar=1 cm

\section{Quantitative analysis of root membrane lipid peroxidation}

Measurement

of malondialdehyde

(MDA) concentration indicates the presence of lipid peroxidation in cells (Jumiati 2016; Siska et al. 2017). The results showed that the highest MDA concentration in the Altreated roots was found in rice cv. Situpatenggang $(16,500$ nmol g-1 FW) followed by Inpago $5\left(16,250 \mathrm{nmol} \mathrm{g}^{-1} \mathrm{FW}\right)$, whereas the lowest MDA concentration was found in rice cv. Hawara Bunar (326 nmol g-1 FW) (Figure 5). The other rice cultivar showed variation from middle to high level of MDA content. High MDA content means the root cell membrane experienced high level of lipid peroxidation.

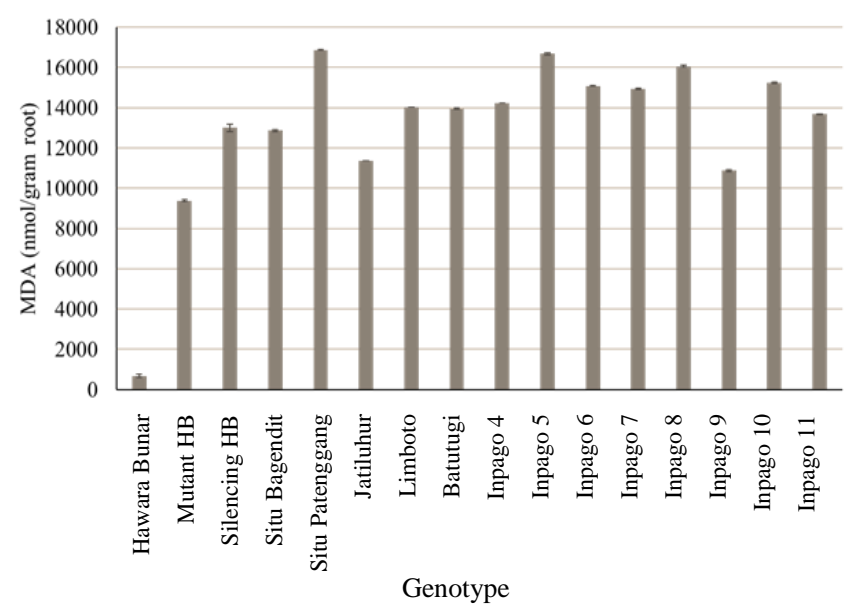

Figure 5. Malondialdehyde (MDA) concentration in the root tips of several rice genotypes treated with $15 \mathrm{ppm} \mathrm{Al}$ for 72 hours 


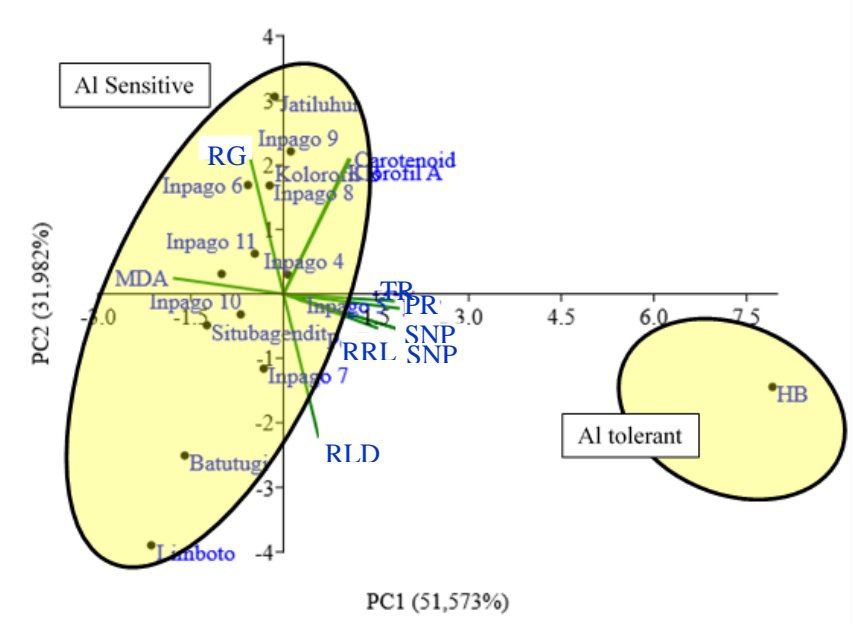

Figure 6. Principal Component Analysis (PCA) of Inpago rice treated with $15 \mathrm{ppm} \mathrm{Al}$ for 72 hours. Primary root growth inhibition (RGI), malondialdehyde content (MDA), relative primary root length (RRL), root length difference (RLD), single nucleotide polymorphism 1 of B11 (SNP1), single nucleotide polymorphism 2 of $B 11$ (SNP2), total root length (TRL), primary root length (PRL).

\section{Level of $\mathrm{Al}$ tolerance in Inpago rice}

The tolerance level of plants against Al stress can be determined by measuring the length of the primary roots such as RGI (Jumiati 2016), RRG (Ma et al. 2014), and RRL (Siska et al. 2017). In addition, MDA values that describe $\mathrm{Al}$ content at the root tip can also be used to determine the tolerance level of plants to Al stress (Siska et al. 2017). Based on principal component analysis (PCA) using root length and MDA characters, the tolerance level of rice plants can be divided into two types, which are Alsensitive and Al-tolerant rice. Rice that has a high tolerance to $\mathrm{Al}$ stress was rice cv. Hawara Bunar and grouped as $\mathrm{Al}$ tolerant rice because it has high PRL and TRL value, whereas the rest of the rice cultivars, which were Jatiluhur, Situpatenggang, Limboto, Situbagendit, Batutugi, Inpago 4, Inpago 5, Inpago 6, Inpago 7, Inpago 8, Inpago 9, Inpago 10, and Inpago 11, were classified into Al-sensitive rice based on high MDA value, low PRL and TRL, as well as low values of other root length characters (Figure 6). Based on correlation and the PCA analyses, it could be suggested that PRL, TRL, and MDA characters could be used to distinguish the level of $\mathrm{Al}$ tolerance of rice cultivars. The high value of PRL and TRL and low MDA content indicates $\mathrm{Al}$ tolerant genotypes, conversely low PRL and TRL and high MDA content indicates Al sensitive genotypes.

\section{Identification of Snpb11 marker}

In this study, we identified SNPs from the B11CAPS marker sequences of observed rice cultivars. We found two SNPs in the sequences, one SNP formed Alul restriction site (Snpb11-1) with G/A substitution and the other SNP was not a restriction site (Snpb11-2) with G/C substitution. The $G$ nucleotides in both SNPs were found in rice cv.
Hawara Bunar, while A in Snpb11-1 and C in Snpbl1-2 were found in the rest of rice cultivars. Both SNPs were located in the introns of the $B 11$ genomic DNA sequence, which is converted to B11CAPS molecular marker. The size of the B11CAPS marker sequence was 520 bp (Figure 7).

\section{Correlation among Snpb11 markers, root growth, and physiological characters}

Correlation between physiological characters of several rice genotypes with Snpb11 markers was analyzed using Pearson correlation. We performed two correlation analyses, i.e.: correlation analysis among characters and SNPs in all rice cultivars grown in normal condition and the other analysis was performed for Al-treated rice cultivars (Figure 8). The results showed that there was a different correlation response between both conditions. In normal condition, there was no significant correlation between two SNPs and all root growth and physiological characters except a strong negative correlation with MDA content (-0.93). Conversely, there was a strong positive correlation between two SNPs and root growth characters (PRL and TRL) and a strong negative correlation with MDA content (-0.90) in the Al-treated rice cultivars. In the latter condition, the MDA has also a strong negative correlation with both PRL and TRL. In both unstressed and Al-stressed rice, there was no significant correlation between two SNPs and leaf chlorophyll as well as leaf carotenoid although among those leaf photosynthetic pigments showed a strong positive correlation (Figure 8).

\section{Discussion}

Application of molecular markers in plant identification and breeding has been widely used. Among the molecular markers used in plant improvement, SNP is one of the molecular markers that showed very robust and reproducible. Snpb11 markers used in this study have been developed from $B 11$ gene sequence, which is one of the $\mathrm{Al}$ tolerance genes in rice. The markers were developed to differentiate the tolerance level among rice cultivars to $\mathrm{Al}$ stress. However, the markers need to be verified through correlation study between selected physiological characters that related to Al tolerance and Snpb11 markers in several rice varieties, especially Inpago cultivars. There are several physiological characters that were analyzed in this study, i.e.: primary root growth characters (RRL, RGI, RLD, RLE), primary root length, total root length, leaf chlorophyll and carotenoid content, $\mathrm{Al}$ accumulation in the root tip, and root cell membrane lipid peroxidation.

Observation on root morphology of rice varieties based on root images showed that rice cv. Hawara Bunar has longer roots compared to the other upland rice after being treated by $15 \mathrm{ppm} \mathrm{Al}$ for 72 hours in minimum nutrient culture (Figure 1). This result is relatively similar to the result of Pambudi (2012), Siska et al. (2017), and Umaiyah (2016) that reported rice cv. Hawara Bunar has significantly longer root compared to other cultivars, such as IR64, when treated by Al. 


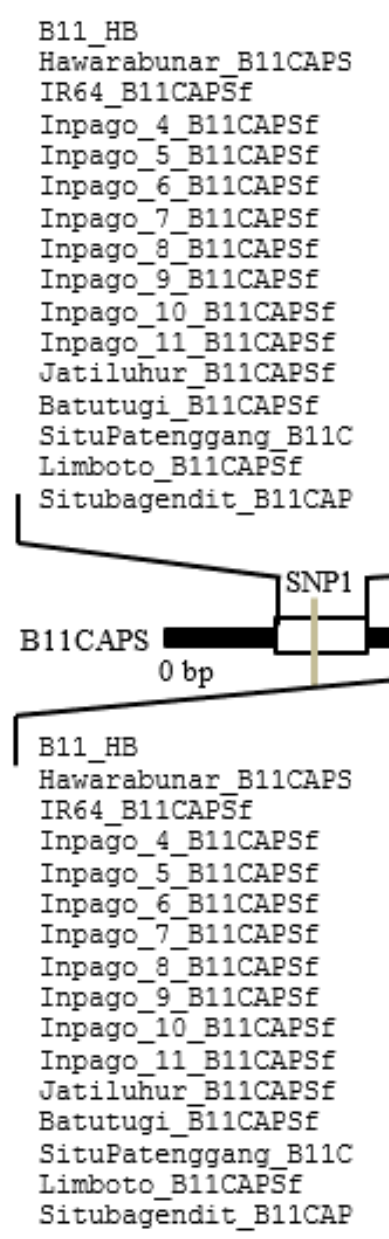

CALATGTCTARARA:ETCTTTAATTGTAGA 120 CAATGTCTAAAAA GETCTTTAATTGTAGAG 120 CAATGTCTAAAA AAETCTTTAATTGIAGAG 120 CAATGTCTAMAAAAETCTTTAATTGTAGAG 120 CAATGTCTAMARAAETCTTTAATTGIAGAG 120 CAATGTCTAAAAAPETCTTTAATTGTAGAG 120 CAATGTCTAMAAAAETCTTTAATTGTAGAG 120 CAATGTCTAMAAPAETCTTTAATTGTAGAG 120 CAATGTCTAAAA A A TCTTTAATTGIAGAG 120 CAATGTCTAAARAAETCTTTAATTGTAGAG 120 CAATGTCTAMAAAAETCTTTAATIGTAGAG 120 CAATGTCTAAAAAATCTTTAATTGTAGAG 120 CAATGTCTAMAAAAETCTTTAATTGTAGAG 120 CAATGTCTAMAAAAETCTTTAATTGTAGAG 120 CAATGTCTAAAAAAETCTTTAATTGTAGA 120 CAATGTCTAAAAAAPTCTTTAMTIGTAGA 120 $* * * * * * * * * * * * t ; * * * * * * * * * * * * * * * *$

1

Figure 7. The sequence of SNPs markers of $B 11$-genomic DNA from in several rice cultivars. The size of $B 11$-genomic DNA is 520 bp. Single nucleotide polymorphism 1 of $B 11$ (Snpb11-1), single nucleotide polymorphism 2 of $B 11$ (Snpb11-2)

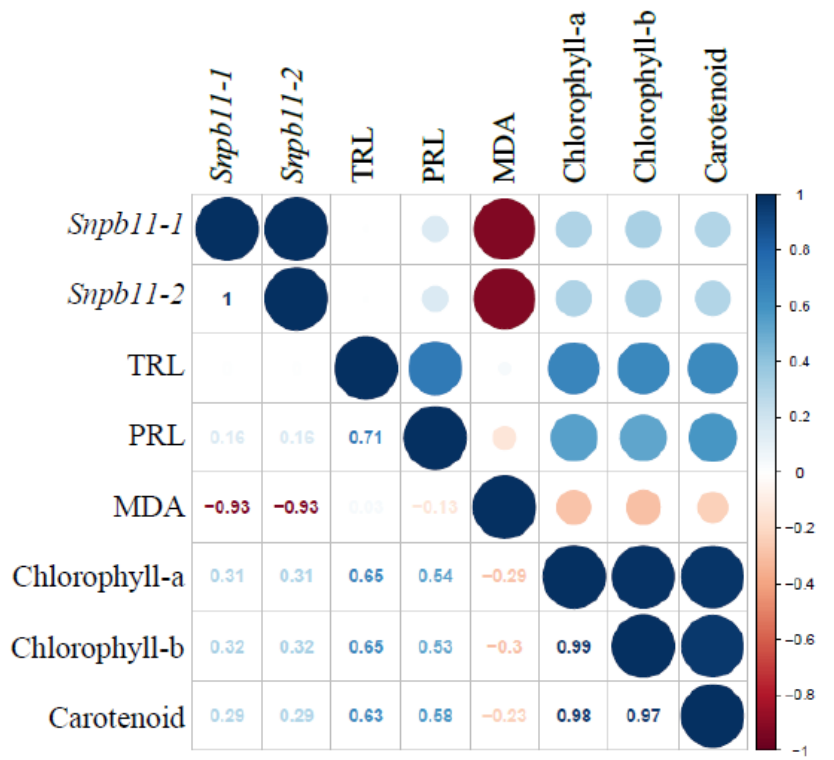

A

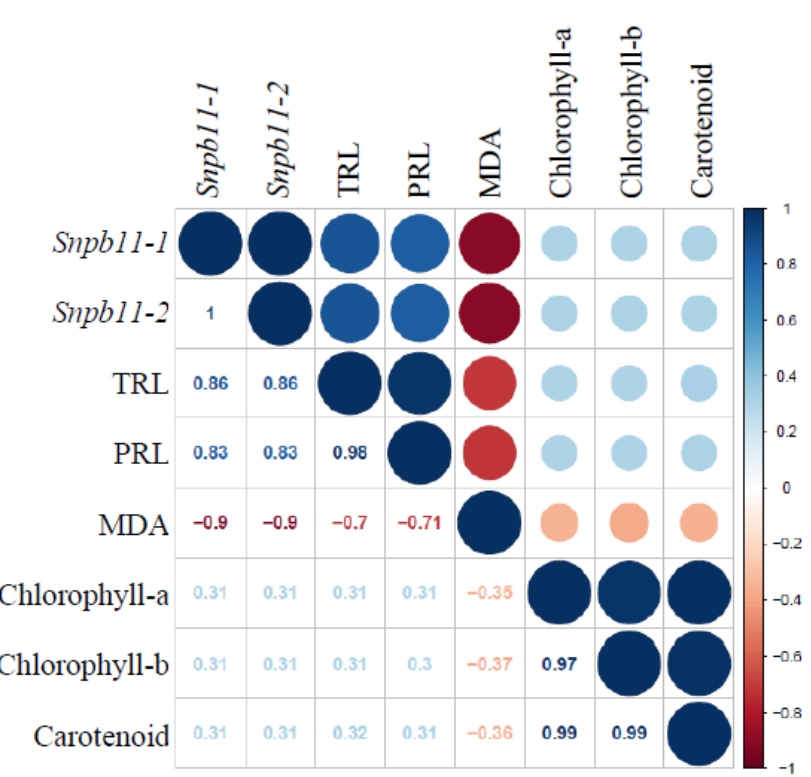

B

Figure 8. Pearson correlation analysis between SNP markers and several physiological characters in normal (a) and $15 \mathrm{ppm} \mathrm{Al}$ treated condition (b). Correlation values are denoted by round shapes and color density differences. Snpb11-1: single nucleotide polymorphism 1 of B11, Snpb11-2: single nucleotide polymorphism 2 of B11, TRL: total root length, PRL: primary root length 
Another Al tolerance parameter, primary root growth character, showed similar results with root morphology, especially rice cv. Hawara Bunar that has a different value with the other rice cultivars. Rice cv. Hawara Bunar had low RGI and RLE, but had high RRL, RLD, PRL, and TRL (Figure 2). Rice genotypes with low RGI and RLE values indicates that those rice roots are less inhibited by $\mathrm{Al}$ and can be classified as Al-tolerant plant (Siska et al. 2017). Another root growth character that can be used as Altolerance parameter is RRL character. The higher RRL value indicates the higher tolerance level of the rice to $\mathrm{Al}$ toxicity (Wijayanto 2013).

The high $\mathrm{Al}$ content in the leaves can produce reactive oxygen species (ROS) and further damage the photosynthetic systems in the leaves by reducing chlorophyll content. In addition, ROS compounds that are produced during $\mathrm{Al}$ stress can reduce and damage proteins in both photosystem I and II devices, which furthermore will be expressed as secondary responses to Al stress (Kochian 1995; Kochian et al. 2015). Al-sensitive Inpago rice has relatively lower chlorophyll and carotenoid content compared to Al-tolerant rice cv. Hawara Bunar (Figure 3). However, the level of chlorophyll and carotenoid content in the leaves cannot describe the Al tolerance level of plants because the change of chlorophyll and carotenoid content in leaves due to $\mathrm{Al}$ stress is a secondary symptom (indirect response) of $\mathrm{Al}$ toxicity through activation of ROS in the cells (Kochian et al. 2015). To obtain more accurate differentiation between Al-tolerant and sensitive plants, $\mathrm{Ma}$ et al. (2014) have examined root growth characters as $\mathrm{Al}$ tolerance parameter because the roots, especially the root tips, are part of the plant organs that are first exposed to $\mathrm{Al}$ in the rhizosphere.

Other physiological characters that could be used for discriminating $\mathrm{Al}$ tolerance in rice genotypes are $\mathrm{Al}$ accumulation in the root tips and lipid peroxidation level in the root cell membranes as have been reported by Siska et al. (2017) when differentiating Al tolerance response of transgenic rice cv. IR64 overexpressing Al tolerance gene, B11, and its wild type. Both $\mathrm{Al}$ accumulation and lipid peroxidation characters were also evaluated in this study to determine the $\mathrm{Al}$ tolerance level among several Inpago rice varieties. As shown in Figure 4, the root tips of rice cv Hawara Bunar showed less intense purple color compared to the other rice varieties after being stained with hematoxylin, which indicated that the root tips of Hawara Bunar accumulated less $\mathrm{Al}$ than that of the other varieties. The similar result is also reported by Jumiati (2016) and Siska et al. (2017) who observed that rice root tip cv. Hawara Bunar shows less intense purple color when stained with hematoxylin after being stressed with $\mathrm{Al}$ compared with that of IR64 and Hawara Bunar mutant that sensitive to Al. Hawara Bunar is considered as Al-tolerant varieties through exclusion mechanism by secreting high citric acid into the rhizosphere when exposed to high $\mathrm{Al}$ toxicity; therefore it accumulates low $\mathrm{Al}$ in the root tip cells (Jumiati 2016, Siska et al. 2017).

Lipid peroxidation level is one of the $\mathrm{Al}$ tolerance parameters in the plant. In this research, the level of lipid peroxidation was observed based on the MDA content produced by the cell. Quantitative analysis of root cell membrane lipid peroxidation showed that the highest MDA content in the root tips was shown by rice cv. Inpago 5, Inpago 8, and Situpatenggang, whereas the lowest MDA content was found in the root tips of rice cv. Hawara Bunar (Figure 5). The results of the histochemical assay (data are not showed) showed similar with the quantitative measurement of lipid peroxidation, where rice cv. Hawara Bunar classified as Al-tolerant rice, whereas rice cv. Inpago is sensitive to Al. High lipid peroxidation level of $\mathrm{Al}$ stressed plants that damage cell membranes are considered as an inability of root cell to overcome the negative effect of ROS produced by $\mathrm{Al}$ toxicity, and therefore such plants are classified as Al-sensitive rice (Siska et al. 2017; Jumiati 2016; Akhmad 2009).

To determine the level of $\mathrm{Al}$ tolerance in several rice cultivars, we performed principal component analysis (PCA). The PCA results showed that rice cv. Hawara Bunar is separated from the other upland rice groups such as Limboto, Batutugi, Inpago 4-11, Jatiluhur, Situpatenggang, and Situbagendit (Figure 6). Roslim (2011), Jumiati (2016), Umaiyah (2016), and Siska et al. (2017) reported that rice cv. Hawara Bunar is classified as Al-tolerant rice. Rice cv. Inpago 4-11 were classified as upland rice that were moderately tolerant to Al based on agronomic characteristics when planted in acid soil (Aprilliani et al. 2017). However, this study showed that Inpago rice 4-11 were not in one group with Hawara Bunar, therefore those varieties are classified into the Alsensitive group. Moreover, rice cv. Situbagendit belongs to an Al-sensitive group. This study also showed similar results with Widiastuti (2014) study that reported rice cv. Situbagendit is Al-sensitive rice. Based on PCA result, there is evidence that Al-tolerant rice has low RGI and MDA content but high RRL, LRD, PRL, TRL, and chlorophyll content. Conversely, Al-sensitive rice has low RRL, LRD, PRL, TRL, and chlorophyll content but high RGI and MDA. Based on biplot analysis on PCA, the characters of PRL, TRL, and RRL determine significantly the grouping of rice cv. Hawara Bunar when compared to RGI, RLD, and MDA characters. In addition, Siska et al. (2017) reported that the PRL and TRL characters have been able to distinguish B11-transgenic rice from its wild type. Therefore, we analyze the PRL and TRL characters to be used for further Pearson correlation analysis.

Single nucleotide polymorphism (SNP) is a molecular marker that is widely used for genetic analysis of many organisms including plants or animals (Ganal et al. 2015; Fendiyanto 2015). SNP markers can be combination between SNP detection and genotyping such as genotyping by sequencing (GBS) to obtain high-precision data (Andrews et al. 2016). However, this combination approach generally requires a high cost. SNP markers can also be detected from the restriction site in aligned DNA sequences of several genotypes. The combination of PCR techniques with digestion with the restriction enzyme at a specific SNP in PCR fragment could produce a marker that is referred to as CAPS markers. However, the use of CAPS 
markers is also relatively expensive because it requires additional cost for restriction enzymes. The recent technique using SNP allele-specific primers are able to detect PCR-based SNP markers that are relatively easy, effective, and inexpensive technique (Gaudet et al. 2009) when compared to SNP arrays, SNP-GBS combination, and CAPS techniques. In this study, we used two SNP markers that were developed based on B11CAPS marker sequences to evaluate the level of $\mathrm{Al}$ tolerance in several rice varieties using correlation approach between SNP markers and physiological characters.

As previously reported by Roslim (2011), B11CAPS marker is able to discriminate rice plant in the F2 population between IR64 and Hawara Bunar allele types based on the ability of restriction enzyme AluI to cut the PCR fragment. We then used the B11CAPS markers to evaluate Inpago rice cultivars and other rice cultivars. The result showed that AluI can only cut Hawara Bunar PCR fragment, whereas the rest of the cultivars including Inpago PCR fragments were not able to be cut, which indicated that those fragments had no AluI restriction site. Then we sequenced all B11CAPS fragments from all rice cultivars used in this study. The result showed that there were two SNP sites in the sequences, one SNP (Snpb11-1) was located on Alul restriction site with G/A nucleotide substitution, and the other (Snpb11-2) was located outside the Alul site with G/C nucleotide substitution (Figure 7).

To verify the relationship between both Snpb11 markers and $\mathrm{Al}$ tolerance trait, we performed Pearson correlation analysis between both Snpb11 markers and physiological characters, i.e.: PRL, TRL, MDA content, chlorophyll and carotenoid content under Al-treated and untreated (control) condition. The result showed that both Snpb11 markers had no significant correlation with leaf chlorophyll and carotenoid content in both conditions (Figure 8). The result also showed that both Snpbll markers had a highly negative correlation with MDA content in both conditions. Interestingly, both Snpb11 markers have a highly positive correlation with PRL and TRL under Al treatment, but no significant correlation between both Snpb11 markers and root length under normal condition. The data indicate that Snpb11 correlates specifically with root characters TRL and PRL in the Al stress condition, which indicated that both SNP markers were closely associated with PRL and TRL characters and able to discriminate the Al tolerance level based on both root characters. This result is in accordance with the study of Siska et al. (2017) who reported that PRL and TRL characters are more closely related to $B 11$ gene when compared to the other root growth characters such as RGI, RRG, or LRD. Thus, PRL and TRL characters can be used as Al-tolerance parameters because they have a strong correlation value with Snpb11, which is a derivative marker of the $B 11$, an Al-tolerance gene. As have been previously considered that the root growth character is the main character that determines the Al-tolerance level in plants, whereas leaf chlorophyll content is just a secondary symptom of plants in response to Al stress (Yamaji et al. 2009; Kochian et al. 2015).

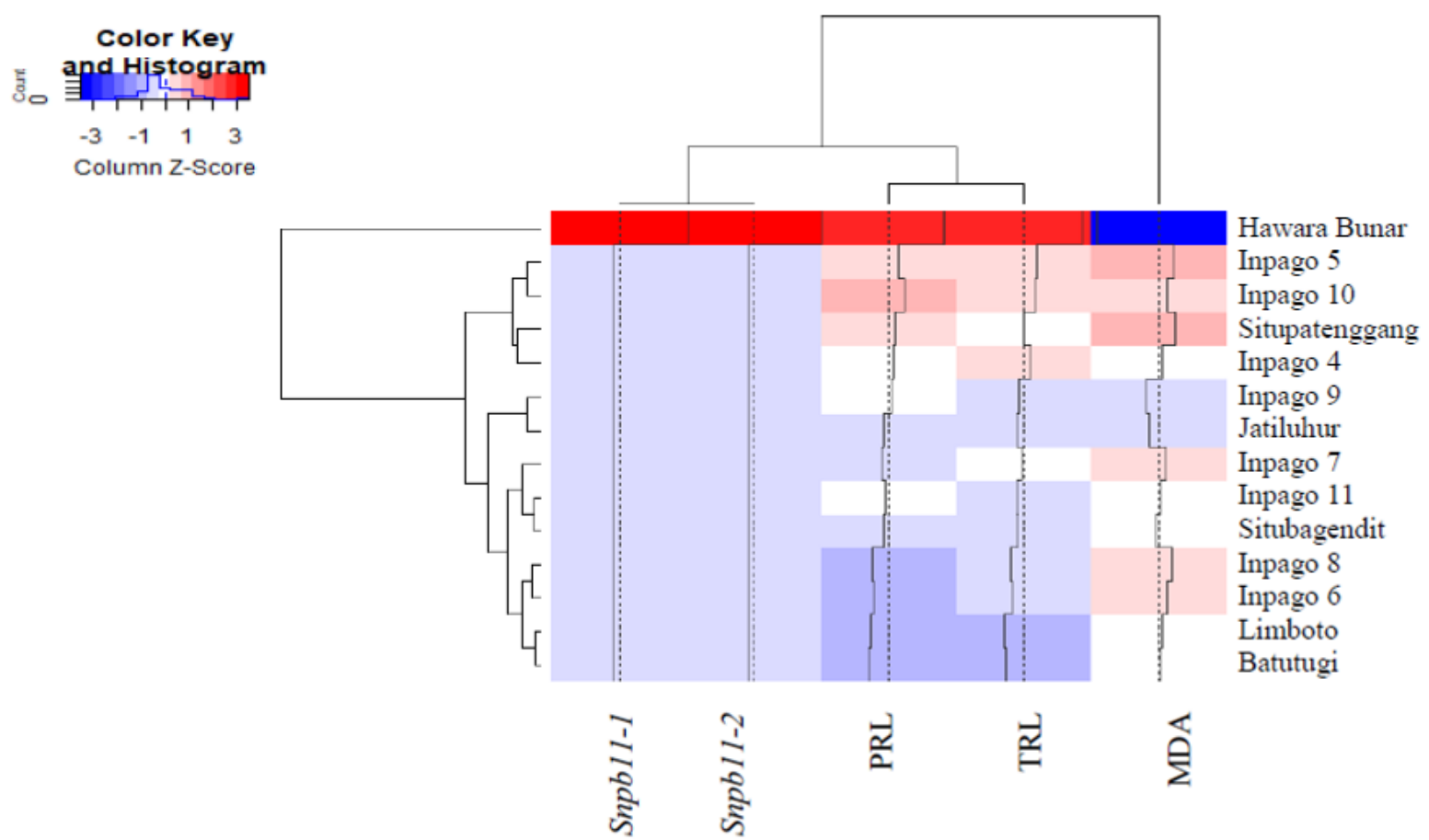

Figure 9. Heatmap of the relationship between physiological characters and Snpb11 markers. The values of all characters in all cultivars have been standardized against averages and standard deviations. Making a matrix is performed by using the R program with a $\mathrm{Z}$-score of -3 to +3 . Single nucleotide polymorphism 1 of B11 (Snpb11-1), single nucleotide polymorphism 2 of B11 (Snpb11-2), primary root length (PRL), total root length (TRL), malondialdehyde content (MDA) 
In order to confirm the relationship among Snpb11, PRL, TRL, and MDA in all rice cultivars, heatmap analysis was carried out and the result confirmed that both Snpb11 are related to each other as well as the relation between PRL and TRL. Those five variables were able to classify all rice cultivars into two main groups, i.e.: Hawara Bunar in one group and other rice cultivars in other groups. The rice cultivars other than Hawara Bunar varied in the level of $\mathrm{Al}$ tolerance as manifested in the dendrogram.

The $B 11$ gene is considered as a gene that plays a significant role in the $\mathrm{Al}$ tolerance level in rice (Ratnasari et al. 2016). Roslim (2011) reported that the B11 gene could be used as a molecular marker to distinguish $\mathrm{Al}$ tolerance level in rice. Therefore, Snpb11 are thought to be a strong marker for discriminating $\mathrm{Al}$ tolerance level of rice genotypes. Since Snpb11 markers correlate strongly with the Al tolerance trait especially PRL and TRL, (Figure 7, 8, 9), PRL and TRL characters can also be used as strong parameters to determine the tolerance level of $\mathrm{Al}$ in rice (Figure 9). Furthermore, PRL character is one of the root physiological characters that are easier to observe, and to measure, and are more practical than that of TRL characters. Thus, in the future to determine the tolerance level of Al in rice, the PRL character and Snpb11 can be used as a selection tool in rice breeding to obtain $\mathrm{Al}$ tolerant varieties. Conversion of Snpb11 markers into PCRbased marker becomes a further important step in order to practically use the Snpbl1 markers as a selection tool in marker-assisted selection program.

\section{ACKNOWLEDGEMENTS}

Authors acknowledged to the Ministry of Research, Technology and Higher Education of Republic of Indonesia for funding this research through Program Magister menuju Doktor untuk Sarjana Unggul (PMDSU) Scholarship for Miftahul Huda Fendiyanto, supervised by Dr. Miftahudin, year 2016-2019.

\section{REFERENCES}

Akaya M, Takenaka C. 2001. Effects of aluminum stress on photosynthesis of Quercus glauca Thumb. Plant and Soil 237: 137 146.

Akhmad. 2009. Analysis of Molecular Markers Linked to Physiologica Characteristics of Aluminum Tolerance Trait in Rice. [Thesis]. Institut Pertanian Bogor, Bogor. [Indonesian]

Andrews KR, Good JM, Miller MR, Luikart G, Hohenlohe PA. 2016. Harnessing the power of RADseq for ecological and evolutionary genomics. Nat Rev Genet 17: 81-92.

Aprilliani S, Suwarno FC, Yullianida. 2017. Rapid testing method for al toxicity tolerance at germination growth stage of upland rice genotype. Bul Agrohorti 5 (1): 126-136.

Awasthi JP, Saha B, Regon P, Sahoo S, Chowra U, Pradhan A, Roy A Panda SK. 2017. Morpho-physiological analysis of tolerance to aluminum toxicity in rice varieties of North East India. PLoS ONE 12 (4): $1-23$

Clark RT, Famoso AN, Zhao K, Shaff JE, Craft EJ. 2013. Highthroughput two-dimensional root system phenotyping platform facilitates genetic analysis of root growth and development. Plant, Cell \& Envir 36: 454-466.
Dere S, Gunes T, Sivaci R. 1998. Spectrophotometric determination of chlorophyll - A, B and total carotenoid contents of some algae species using different solvents. Trop J Bot 22: 13-17.

Fendiyanto MH. 2015. Analysis of B11 Gene Promoter in Rice (Oryza sativa L.) cv. Hawara Bunar and IR64. [Thesis]. Institut Pertanian Bogor, Bogor. [Indonesian]

Ganal MW, Polley A, Graner EM, Plieske J, Wieseke R, Luerssen H, Durstewitz G. 2012. Large SNP arrays for genotyping in crop plants. J Bioscience 37: 821-828.

Gaudet M, Fara AG, Beritognolo I, Sabatti M. 2009. Allele-specific PCR in SNP Genotyping in Single Nucleotide Polymorphisms: Methods and Protocols. Humana Press, New York.

Heath RL, Packer L. 1968. Photo peroxidation in isolated chloroplasts. I. Kinetics and stoichiometry of fatty acid peroxidation. Arch Biochem Biophys 125: 189-198.

Hu X, Tanaka A, Tanaka R. 2013. Simple extraction methods that prevent the artifactual conversion of chlorophyll to chlorophyllide during pigment isolation from leaf samples. Plant Met 9 (19): 1-13.

Jung JKH, McCouch S. 2013. Getting to the roots of it: genetic and hormonal control of root architecture. Front Plant Sci 4: 179-186.

Jumiati. 2016. Root Physiology Characteristics of Aluminum Sensitive Mutant Rice and the Pattern of Its Inheritance. [Thesis]. Institut Pertanian Bogor, Bogor. [Indonesian]

Karama AS, Abdurachman A. 1993. Optimization of Environmental Use of Land Resources in Indonesia. Pusitbang Pres, Bogor. [Indonesian]

Kochian LV. 1995. Cellular mechanisms of aluminum toxicity and resistance in plants. Annu Rev Plant Physiol Plant Mol Biol 46: 237260.

Kochian LV, Hoekenga OA, Piñeros MA. 2004. How do crop plants tolerate acid soils? Mechanisms of aluminum toxicity and phosphorus efficiency. Annu Rev Plant Biol 55: 459-463.

Kochian LV, Pĩneros MA, Liu J, Magalhaes JV. 2015. Plant adaptation to acid soils: the molecular basis for crop aluminum resistance. Annu Rev Plant Biol 66: 1-28.

Lander JP. 2014. R for Everyone: Advanced Analytics and Graphics. Addison-Wesley, Boston.

Lynch JP, Saint-Clair SB. 2004. Mineral Stress: the missing link in understanding how global climate change will affect plants in real word soils. Field Crops Res 90: 101-115.

Ma JF, Chen ZC, Shen RF. 2014. Molecular mechanisms of Al tolerance in gramineous plants. Plant Soil 381: 1-12.

Meriga B, Attitalla IH, Ramgopal M, Ediga A, Kavikishor PB. 2010. Differential tolerance to aluminum toxicity in rice cultivars: involvement of antioxidative enzymes and possible role of aluminum resistant locus. Acad J Plant Sci 3 (2): 53-63.

Miftahudin, Scholes GJ, Gustafson JP. 2002. AFLP markers tightly linked to the aluminum-tolerance gene Alt3 in rye (Secale cereal L.). Theor Appl Genet 104: 626-631.

Miftahudin, Nurlaela, Juliarni. 2007. Uptake and distribution of aluminum in root apices of two rice varieties under aluminum stress. Hayati 14 (3): 110-114.

Miftahudin, Chikmawati T, Utami DW, Hanarida I. 2008. QTL Analysis of Aluminum Tolerance Trait in Rice. IPB Pres, Bogor. [Indonesian]

Mihailovic N, Drazic G, Vucinic Z. 2008. Effects of aluminium on photosynthetic performance in Al-sensitive and Al-tolerant maize inbred lines. Photosynthetica 46 (3): 476-480.

Nguyen VT, Burow MD, Nguyen HT, Le BT, Le TD, Paterson AH. 2001. Molecular mapping of genes conferring aluminum tolerance in rice (Oryza sativa L.). Theor Appl Genet. 102: 1002-1010.

Nguyen BD, Brar DS, Bui BC, Nguyen TV, Pham LN, Nguyen HT. 2003. Identification and mapping of the QTL for aluminum tolerance introgressed from the new source, Oryza rufipogon Griff., into indica rice (Oryza sativa L.). Theor Appl Genet. 106: 583-593.

Ohki K. 1986. Photosynthesis, chlorophyll, and transpiration responses in aluminum stressed wheat and sorghum. Crop Science 26: 572-575.

Okonechnikov K, Golosova O, Fursov M. 2012. Unipro UGENE: a unified bioinformatics toolkit. Bioinformatics 28 (8): 1166-1167.

Pambudi A. 2012. Genetic Rice Transformation (Oryza sativa L.) Using Aluminum Tolerant Genes Candidates. [Thesis]. Institut Pertanian Bogor, Bogor. [Indonesian]

Panda SK, Baluska F, Matsumoto H. 2009. Aluminum stress signaling in plants. Plant Signal Behav 4 (7): 592-597.

Piere A, Gonkhamdee S, Jourdan C, Maeght JL. 2013. IJ_Rhizo: an opensource software to measure scanned images of root samples. Plant Soil 373: 531-539. 
Roslim DW. 2011. Isolation and Characterization of Aluminum Tolerant Genes from Rice. [Dissertation]. Institut Pertanian Bogor, Bogor. [Indonesian]

Roy B, Bhadra S. 2014. Effects of toxic levels of aluminium on seedling parameters of rice under hydroponic culture. Rice Sci 21 (4): 217 223.

Sasaki T, Yamamoto Y, Ezaki E, Katsuhara M, Ryan PR, et al. 2004. A gene encoding an aluminum-activated malate transporter segregates with aluminum tolerance in wheat. Plant J 37: 645-653.

Sen G, Eryilmaz IE, Ozakca D. 2014. The effect of aluminium-stress and exogenous spermidine on chlorophyll degradation, glutathione reductase activity and the photosystem II D1 protein gene (psbA) transcript level in lichen Xanthoria parietina. Phytochemistry 98: 5459.

Siska DM, Hamim, Miftahudin. 2017. Overexpression of B11 gene in transgenic rice increased tolerance to aluminum stress. Hayati $\mathrm{J}$ Biosci 24: 96-104.
Tsutsui T, Yamaji N, Ma JF. 2011. Identification of a cis-acting element of ART1, a C2H2-type zinc-finger transcription factor for aluminum tolerance in rice. Plant Physiol 156: 925-931.

Umaiyah EI. 2016. Physiological, Morphological, and Anatomical Responses of Transgenic Hawara Bunar Rice Roots Experiencing Silencing B11 Genes to Low pH and Aluminum Stresses. [Thesis]. Institut Pertanian Bogor, Bogor. [Indonesian]

Widiastuti FJ. 2014. Stability of Aluminum Tolerant Genes in Rice cv. Situ Bagendit from In Planta Transformation Approach. [Thesis]. Institut Pertanian Bogor, Bogor. [Indonesian]

Wijayanto A. 2013. The Molecular Markers Application in IR64 / Hawara Bunar Cross-Population Selection to Obtain Aluminum Tolerant Rice Genotypes. [Thesis]. Institut Pertanian Bogor, Bogor. [Indonesian]

Yamaji N, Huang CF, Nagao S, Yano M, Sato Y, Nagamura Y, Ma F. 2009. A zinc finger transcription factor ART1 regulates multiple genes implicated in aluminum tolerance in rice. Plant Cell 21: 33393349 